\title{
The Savings-Investment Relationship: Cointegration and Causality Evidence from Uemoa Countries
}

\author{
Loesse Jacques ESSO \\ Ecole Nationale Supérieure de Statistique et d'Economie Appliquée (ENSEA) Abidjan- Côte d'Ivoire \\ Economic Policy Analysis Centre (CAPEC) / Ivorian Centre for Economic and Social Research (CIRES) \\ Tél: 225-22-444-124, Fax: 225-22-485-168. 08 BP 3 Abidjan 08, Côte d'Ivoire \\ E-mail: lj.esso@gmail.com
}

Yaya KEHO

Ecole Nationale Supérieure de Statistique et d'Economie Appliquée (ENSEA) Abidjan- Côte d'Ivoire

Economic Policy Analysis Centre (CAPEC) / Ivorian Centre for Economic and Social Research (CIRES)

Tél: 225-22-444-124, Fax: 225-22- 485-168. 08 BP 3 Abidjan 08, Côte d'Ivoire

E-mail: yayakeho@yahoo.fr

JEL Classification: C32, E44.

\begin{abstract}
The relationship between saving and investment has been sharply debated in the empirical literature following the pioneering work of Feldstein and Horioka (1980). This paper contributes to this literature. As opposed to most previous studies, which have used panel estimation methods, we test for cointegration and causality between saving and investment in time-series settings for the UEMOA member countries by using the bounds test for cointegration proposed by Pesaran et al. (2001) and the Granger causality test of Toda and Yamamoto (1995). The results show that domestic saving plays an active role in financing investment in only three countries. For the other four countries, the domestic savings rate and investment rate are not related.
\end{abstract}

Keywords: Investment, Saving, Cointegration, Causality

\section{Introduction}

Savings and investment are key requirements for growth and development. However, lack of savings and investment are common in developing countries. To overcome the lack of adequate domestic savings, foreign savings via unrestricted capital flows are encouraged. The issue of low levels of domestic savings is a major problem in small developing states because of high unemployment, low wages, engagement of a large proportion of the population in the informal sector, and poor performance of the economy. The interaction between saving and investment has become a subject of great interest and debate among macroeconomists. The debate has traditionally revolved around two issues. The first relates to whether domestic investment results in domestic savings, and the second relates to how domestic investment affects savings. A growing body of literature has emerged, both at the theoretical and empirical level, attempting to answer these issues. Conventional thinking holds that savings is an essential element in promoting investment and therefore economic growth. According to this view, low levels of domestic savings in some developing countries condemn them to an uncomfortable choice between low investment and growth, or excessive reliance upon foreign capital which makes them vulnerable to financial crises. Empirical research, however, does not conclusively support this conventional belief. Empirical findings are mixed and controversial across countries, data and methodologies. Most empirical works are based on panel or cross-country regressions and may be criticised since they impose cross-sectional homogeneity on coefficients that in reality may vary across countries because of differences in institutional, social and economic structures. The overall result obtained from panel or cross-section regressions represents only an average relationship, which may or may not apply to individual countries in the sample. To enhance our understanding of the causal relationship between saving and investment it is essential to perform studies on individual countries using time series data.

This paper makes an empirical contribution to the literature on the saving-investment relationship for the member countries of the West African Economic and Monetary Union (UEMOA), namely Benin, Burkina Faso, Côte d'Ivoire, Mali, Niger, Senegal and Togo. We aim to investigate two broad objectives. The first is to determine whether saving and investment rates are cointegrated, and the other is to identify the direction of causality between the two variables. 
Presence of cointegration suggests that capital is at least somewhat immobile internationally, while lack of cointegration suggests perfect capital mobility (Miller, 1988). Understanding the causal relationship between saving and investment is relevant for its policy implications, specifically for countries of a common monetary area. Indeed, budget deficits reduction within monetary unions is commonly based on the belief that deficits affect negatively domestic savings, and therefore domestic investment. Behind this interpretation there is the idea that domestic saving systematically causes domestic investment. If this saving causes investment in all countries, then promoting domestic savings should be a high priority to boost investment and economic growth. In this case, the deficit target within UEMOA is absolutely relevant. Alternatively, if causality runs from investment to saving, saving-promoting policies are likely to be unsuccessful and may involve economic inefficiencies. Policy emphasis should be shifted away from saving and concentrated in removing the impediments to investment. In the presence of heterogeneity in the causal relationship between saving and investment, the fiscal rule becomes similar to an asymmetric shock striking the member countries. As it increases the domestic savings, it will be beneficial only for countries where causality runs from saving to investment. Given these arguments the issue regarding the causality between savings and investment is of great interest for UEMOA member countries. By examining this relation this paper will offer a guideline to help the policymakers in formulating their policies in terms of encouraging domestic saving and investment.

Unlike most empirical studies, this work uses innovative econometric methodologies to examine the relationship between saving and investment. Specifically, existing empirical work on cointegration and causality uses standard Engle and Granger (1987) and Johansen (1988) cointegration tests and the Granger-causality-type tests to investigate the long-run relationship and the direction of causality. Our paper adopts different methodological approaches, namely the bounds test to cointegration proposed by Pesaran et al. (2001) and the Toda and Yamamoto (1995) test for non-causality. These tests are relatively more efficient in small sample data sizes as is the case in most empirical studies on African countries, and are particularly appropriate for series for which the order of integration is not known or may not be necessarily the same for all variables of interest.

The remainder of this paper is organized as follows. Section 2 briefly reviews some of the theoretical and empirical literature regarding the dynamic relationships between saving and investment. Section 3 highlights the econometric framework. Section 4 presents the data and empirical results. Finally, section 5 offers a brief summary and gives some concluding remarks.

\section{Literature Review}

Investment is a central macroeconomic variable. Its fluctuations account for a large fraction of cyclical volatility of output and income, and most economists link high rates of investment to long run economic growth. Many works have attempted to investigate the theoretical and empirical relationship between investment and saving. Theoretically, for classical and neoclassical economists, the interest of the capital market is determined regarding investment and saving. Following Goldsmith (1969), McKinnon (1973), and Gurley and Shaw (1955), economic development creates demand for particular types of financial arrangements, and the financial system responds automatically to these demands. According to this view, the financial system of a country mobilizes saving and improves the allocation of saving to investment. According to Bencivenga and Smith (1991), the financial system allows altering the composition of saving in a way that is favourable to capital accumulation. Influential economists such as Robinson (1952) and Kuznets (1955), however, contend that the role of financial development is overstated or that financial development follows expansion of the real economy. This would indicate, in contrast to McKinnon-Shaw and the endogenous growth theorists that causality, if it exists, runs from growth to financial development.

This study is linked to the endogenous growth literature which stresses the significance of financial development for long-run economic growth through the impact of financial sector services on capital accumulation and technological innovation. These services include mobilizing savings, acquiring information about investments and allocating resources, monitoring managers and exerting corporate control, and facilitating risk amelioration. As shown by Romer (1986), Lucas (1988), and Rebelo (1991) - and subsequent endogenous growth studies, finance tends to promote capital investment.

Baxter and Crucini (1993) build a theoretical framework to explain the correlation between investment and saving. Their analysis is carried out within the context of a two-country, one-sector, stochastic growth model driven by exogenous shocks to productivity. Although Caprio and Howard (1984), Roubini (1988), Summers (1988), for instance, have suggested that policy reactions are the explanation for observed saving-investment correlations, Baxter and Crucini's (1993) model generates plausible correlations in the presence of completely passive fiscal policy. In their analysis, country size is an important determinant of saving-investment correlations.

To the empirical point of view, one of the most stable regularities observed in data is the fact that national saving rates are highly correlated with national investment rates, both in time series analyses of individual countries and in cross-sections in which each country is treated as a single point data. The debate over the relationship between saving and investment has been initiated by the work of Feldstein and Horioka (1980). According to Feldstein and Horioka, if 
capital is perfectly mobile, investors care only about the rate of return on their investments and not about which country they invest in. This means that domestic saving need not be related to domestic investment under perfect international capital mobility. On the basis of this idea, Feldstein and Horioka (1980) regressed domestic investment ratio on domestic saving ratio for cross-sectional samples of 16 OECD countries over the period 1960-1974 in order to assess how mobile capital was among them. They found that the estimated regression coefficients, which they termed "saving-retention coefficients", were all close to one, indicating that most incremental saving tends to remain in the country of origin. This finding was surprising since it suggested that capital was closer to being completely immobile than perfectly mobile internationally. Their results also supported crowding out and implied that a country's growth prospects are closely tied to its saving effort. Accordingly, policies that promoted saving would impact favourably on growth.

The traditional view is that the level of domestic saving determines the domestic investment. Indeed, the level of saving determines the interest rate and thus the cost of investment, which in turn influences the demand for new capital. In this sense, low investment rate is related to low saving rate. The positive relationship between domestic saving and domestic investment is often viewed as evidence of imperfect international capital flows and various country-specific institutional and non-institutional rigidities. The widespread view that the saving-investment coefficient is simply associated with the degree of capital mobility has been heavily criticized. Alternative interpretations are commonly found in the literature. The first is the long-run current account targeting which is likely to produce a high saving-investment coefficient and, most notably, the intertemporal budget constraint which implies that saving and investment are cointegrated with a unit coefficient regardless of the degree of capital mobility. The second approach to interpret the saving-investment coefficient is related to the country size. Georgopoulos and Hejazi (2005) argue that the Feldstein and Horioka's result simply reflects the fact that a large country is more reliant on domestic sources of financing. Consistent with this interpretation, Murphy (1984), Baxter and Crucini (1993) and Mamingi (1994) find that smaller OECD or developing countries exhibit higher capital mobility than larger ones. This finding is attributed to the fact that smaller countries cannot influence world interest rates, and thus their saving-investment correlation is not biased upwards. The third interpretation is related to the existence of a home bias due to the association of high costs with foreign markets which reduce the international diversification of portfolios (Georgopoulos and Hejazi, 2005; Hericourt and Maurel, 2005). The fourth interpretation suggests that the saving-investment correlation coefficient reflects the substitutability between domestic and external savings (Sachsida and Caetano, 2000). The last interpretation represents a special case and refers to highly integrated regions and currency unions, such as the European Union. Blanchard and Giavazzi (2002) argue that a weaker saving-investment association may simply reflect higher financial and trade integration.

Feldstein and Horioka finding stimulated a large body of empirical works where more of such works have focused on the developed countries with little performed on developing countries. Empirical works vary significantly in terms of the methodology employed, as well as the data set and sample periods covered. The Feldstein and Horioka result has been mainly replicated using cross-section regressions (see among others, Feldstein, 1983; Obstfeld, 1995), and panel estimation techniques (Chakrabarty, 2006; Georgopoulos and Hejazi, 2005; Nell and Santos, 2008; Fouquau, Hurlin and Rabaud, 2008; Kollias, Mylonidis and Paleologou, 2008, Coakley and Kulasi, 1997; Oh et al. 1999). Time-series analysis has provided a wider dispersion of saving-investment coefficients (see among others, Kim, 2001; Kim, Kim and Wang, 2007).

Kollias, Mylonidis, and Paleologou (2008) analyse the saving-investment correlation for 15 European Union member countries, using the ARDL approach and panel regressions. Their study validates the Feldstein-Horioka interpretation of the saving-investment correlation, but the evidence from the ARDL approach does not point to any particular direction in terms of country size, or level of development, or economic and capital market structure. Panel regressions yield a saving-investment coefficient in the range of $0.148-0.157$. This finding is attributed to higher capital mobility, lower transaction costs in the international capital markets, and the declining status of long-run current account targeting as a primary government objective. Telatar, Telatar, and Bolatoglu (2007) re-examine the savings-investment nexus using data for some European countries. Applying a Markov-switching model with heteroskedastic disturbances, they find that the correlation coefficients are unstable due to the policy regime changes consistent with the Lucas critique. Fouquau, Hurlin and Rabaud (2008) propose an original framework to study the influence of factors such as degree of openness, country size and current account on the saving-investment relationship originated by Feldstein and Horioka. Using panel threshold regression models, they establish country-specific and time-specific saving retention coefficients for 24 OECD countries over the period 1960-2000. These coefficients are importantly influenced by degree of openness, country size and current account to GDP ratios.

There is a further set of papers which consider more technical issues in studies of the Feldstein-Horioka puzzle. The empirical estimates are generally sensitive to the estimation method used. For example, Krol (1996) establishes that improvements in the estimating procedure can be obtained by the use of a more general approach than OLS, such as a 
fixed effects panel regression procedure. These estimating techniques result in a reduction in the Feldstein-Horioka correlation, thus reducing the estimated home bias.

\section{Econometric Methodology}

Econometric literature proposes different methodological alternatives to empirically analyse the long-run relationships and dynamics interactions between two or more time-series variables. The most widely used methods include the two-step procedure of Engle and Granger (1987) and the full information maximum likelihood-based approach due to Johansen (1988) and Johansen and Juselius (1990). All these methods require that the variables under investigation are integrated of order one. This inevitably involves a step of stationarity pre-testing, thus introducing a certain degree of uncertainty into the analysis. In addition, these tests suffer from low power and do not have good small sample properties (Cheung and Lai, 1993; Harris, 1995). Due to these problems, this study makes use of two newly developed approaches to cointegration and causality that have become popular in recent years.

\subsection{The Bounds testing approach to cointegration}

The bounds testing approach to cointegration was introduced by Pesaran et al. (2001). The main advantage of the bounds testing approach is that it can be applied irrespective of whether the regressors are purely I(0), I(1) or mutually cointegrated. Another advantage is that the test is relatively more efficient in small sample data sizes as is the case in most empirical studies on African countries. This test is particularly appropriate for small samples in which the order of integration is not known or may not be necessarily the same for all variables of interest.

The bounds test involves estimating by ordinary least squares the following unrestricted error correction model (UECM) considering each variable in turn as a dependent variable:

$$
\Delta I_{t}=\beta_{0}+\sum_{i=1}^{p} \beta_{1 i} \Delta I_{t-i}+\sum_{i=0}^{p} \gamma_{1 i} \Delta S_{t-i}+\eta_{1} I_{t-1}+\eta_{2} S_{t-1}+e_{1 t}
$$

where $I_{t}$ and $S_{t}$ denote domestic investment and savings as share of GDP. The structural lags are determined by using minimum Akaike's information criteria (AIC). To depict the presence of cointegration the estimated coefficients of lagged level variables are restricted equal to zero. Thus the null hypothesis for no cointegration is:

$$
H_{0}: \eta_{1}=\eta_{2}=0
$$

The null hypothesis is tested by the mean of the $F$-test which has an asymptotic non-standard distribution. Thus, the calculated F-statistic is compared with two asymptotic critical values tabulated by Pesaran et al. (2001). The lower critical value assumes that all the regressors are $\mathrm{I}(0)$, while the upper critical value assumes that they are I(1). Therefore, if the computed F-statistic is greater than the upper critical value, the null of no cointegration is rejected and we conclude that saving and investment share a long-run level relationship. If the calculated F-statistic is below the lower critical value, then the null hypothesis of no cointegration cannot be rejected regardless of the orders of integration of the variables. On the other hand, if it falls inside the critical value band, the test is inconclusive unless we know the order of integration of the underlying variables.

If a cointegration relationship is observed between the series, Bardsen's (1989) method will be used to compute the short and long run coefficients. From the estimation of (1), the long-run coefficient is computed as the coefficient of the one lagged level explanatory variable divided by the coefficient of the one lagged level dependent variable and then multiplies with a negative sign. Thus, under the alternative of interest $\eta_{1} \neq 0$ and $\eta_{2} \neq 0$, the long-run level relationship between investment and saving is described by:

$$
I_{t}=\theta_{0}+\theta_{1} S_{t}+v_{t}
$$

where $\theta_{0}=-\beta_{0} / \eta_{1}$ and $\theta_{1}=-\eta_{2} / \eta_{1}$, and $v_{t}$ is a zero-mean stationary process.

\subsection{The Toda-Yamamoto approach to Granger causality test}

The bounds test assumes the dependent variable to be I(1) and the regressors to be either I(0) or I( 1$)$. The procedure cannot be applied if the dependent variable of interest is $\mathrm{I}(0)$ and would crash in the presence of I(2) variable. To complement the bounds test approach and derive inference regarding the direction of causality between saving and investment, we use the methodology proposed by Toda and Yamamoto (1995). This procedure has the advantage of not requiring pretesting for cointegration properties of the system. Thus it overcomes the pre-test biased associated with unit root and cointegration tests. More importantly, the Granger causality tests can be implemented regardless of the orders of integration of the underlying variables. Performed directly on the coefficients of the levels VAR, Toda and Yamamoto methodology minimizes the risk associated with possibly wrongly identifying the orders of integration of the series, or the presence of cointegration relationship (Giles, 1997; Mavrotas and Kelly, 2001). The basic idea is to artificially augment the correct 
VAR order, k, with $d_{\max }$ extra lags, where $d_{\max }$ is the maximum likely order of integration of the series in the system. The empirical model to be estimated is specified as follows:

$$
\begin{gathered}
I_{t}=\alpha_{0}+\sum_{i=1}^{k} \alpha_{1 i} I_{t-i}+\sum_{j=k+1}^{k+d_{\max }} \alpha_{2 j} I_{t-j}+\sum_{i=1}^{k} \beta_{1 i} S_{t-i}+\sum_{j=k+1}^{k+d_{\max }} \beta_{2 j} S_{t-j}+e_{1 t} \\
S_{t}=\phi_{0}+\sum_{i=1}^{k} \phi_{1 i} S_{t-i}+\sum_{j=k+1}^{k+d_{\max }} \phi_{2 j} S_{t-j}+\sum_{i=1}^{k} \delta_{1 i} I_{t-i}+\sum_{j=k+1}^{k+d_{\max }} \delta_{2 j} I_{t-j}+e_{2 t}
\end{gathered}
$$

The null hypothesis that saving does not cause investment is formulated as follows:

$$
\beta_{11}=\beta_{12}=\ldots=\beta_{1 k}=0
$$

The system given by equations (4) and (5) is estimated using the Seemingly Unrelated Regression technique (Rambaldi and Doran, 1996). A Wald test is then carried out to test the hypothesis (6). The computed Wald-statistic has an asymptotic chi-square distribution with $k$ degrees of freedom.

\section{Data and Empirical results}

This study uses time series annual data on gross domestic saving and gross domestic investment as share of GDP for the UEMOA member countries. Except Guinea-Bissau, countries under investigation include Benin, Burkina Faso, Côte d'Ivoire, Mali, Niger, Senegal and Togo. All the data are extracted from the 2007 world development indicators tapes of the World Bank (2007).

Before we proceed with the bounds test, we perform the Augmented Dickey-Fuller (1979) and Phillips-Perron (1988) unit-root tests (ADF and PP hereafter, respectively) to determine the order of integration of each variable. This is to ensure that none of the variables is I(2) so as to avoid spurious results in bounds test. The results reported in Table 1 reveal that saving and investment have unit root for all countries except for Mali and Togo, for which investment is stationary, and Niger for which saving is stationary. However, after taking the first difference, the series appear to be stationary in all countries.

[Table 1 about here]

We can now confidently apply the bound test procedure to examine the presence of long-run relationships between saving and investment. We use the Akaike Information Criterion to determine the appropriate lag structure. Table 2 reports the results of the F-statistic test when each variable is considered as a dependent variable. As can be seen from Table 2, the computed F-statistic appears to be lower than the upper critical values at $5 \%$ of significance for all countries except for Benin and Niger.

[Table 2 about here]

For these two countries there is evidence of cointegration when investment is the dependent variable. The long-run coefficient estimates suggest imperfect capital mobility in the case of Benin and complete capital immobility in Niger. For the rest of the countries results indicate capital mobility, that is, investment is independent of domestic saving.

To complement the above findings, we proceed to causality tests using the Toda and Yamamoto procedure. As the maximum order of integration of the series under investigation is one, the Toda and Yamamoto test involves the addition of one extra lag of each of the variables to control for potential cointegration. Results of the causality tests are presented in Table 3. As can be learned from the p-values of the Wald statistic, there is evidence of unidirectional causality running from saving to investment in Benin, Côte d'Ivoire and Niger. For the remaining countries, no evidence of causality is detected between saving and investment.

[Table 3 about here]

To sum up, the empirical findings suggest that Benin, Côte d'Ivoire and Niger are characterized by a degree of capital immobility. Therefore all increase in domestic savings will not flow out of these countries to other countries, but will induce an increase in domestic investment rate. This gives rise to the importance of saving-promoting policies. On the contrary, in the rest of the countries domestic saving does not play an active role in financing domestic investment. This shows capital mobility with domestic investment being financed by foreign saving rather than domestic saving.

\section{Conclusion}

The objective of this paper is to empirically investigate the relationship between saving and investment for UEMOA countries. To this end, we used time series data on saving and investment rates. Since it is recognized that inferences based on standard approaches of unit root and cointegration tests may yield misleading results, we followed the bounds testing approach to cointegration proposed by Pesaran et al. (2001) and the Granger-causality test of Toda and Yamamoto (1995). Empirical findings are mixed across countries. The results from these tests provided support to the 
view that investment is positively related to domestic savings in only three countries out of seven, namely Benin, Côte d'Ivoire and Niger. For the other four countries, investment is not related to domestic savings. This implies that the bulk of the investment in these countries is not being financed by domestic saving but by foreign saving. Hence, economic policies may be focused on the incitation of investment and the reduction of capital outflows for Burkina Faso, Mali, Senegal and Togo. However, Benin, Côte d'Ivoire and Niger are characterized by imperfectly mobile capital, corroborating some degrees of imperfections mainly in political risk (Côte d'Ivoire), human capital (Niger), and infrastructures (Benin).

The findings of this paper accord with the view of other empirical studies that the relationship between saving and investment cannot be generalized across countries because these results are country-specific.

\section{References}

Bardsen, G. (1989). Estimation of Long-Run Coefficients in Error-correction Models. Oxford Bulletin of Economics and Statistics, 51, 345-350.

Baxter, M. and Crucini, M. J. (1993). Explaining Saving-Investment Correlations. American Economic Review, 88, 416-436.

Bencivenga, V. R. and Smith, B. (1991). Financial Intermediation and Endogenous Growth. Review of Economic Studies, 58, 195-209.

Blanchard, O. and Giavazzi, F. (2002). Current Account Deficits in the Euro Area: The end of the Feldstein-Horioka Puzzle? Brookings Papers on Economic Activity, 2, 147-186.

Caprio, G. A., Jr. and Howard, D. H. (1984). Domestic Saving, Current Accounts, and International Capital Mobility. International Finance Discussion Paper n²44, Federal Reserve Board, Washington, DC.

Chakrabarti, A. (2006). The Saving-Investment Relationship Revisited: New Evidence from Multivariate Heterogeneous Panel Cointegration Analyses. Journal of Comparative Economics, 34, 402-419.

Cheung, Y-W. and Lai, K. S. (1993). Finite-sample sizes of Johansen's likelihood ratio test for cointegration. Oxford Bulletin of Economics and Statistics, 55, pp 313-328.

Coakley, J., and Kulasi, F. (1997). Cointegration of Long Span Saving and Investment. Economics Letters, 54, 1-6.

Dickey, D. A. and Fuller, W. A. (1979). Distribution of the Estimators for Autoregressive Time Series with a Unit Root. Journal of the American Statistical Association, 74, 427-431.

Engle, R. F. and Granger, C. W. J. (1987). Co-integration and Error Correction: Representation, Estimation, and Testing. Econometrica, 55, 251-276.

Feldstein, M. and Horioka, C. (1980). Domestic Saving and International Capital Flows. Economic Journal, 90, 317-323.

Feldstein, M. (1983). Domestic Saving and International Capital Movements in the Long Run and the Short Run. European Economic Review, 21, 129-151.

Fouquau, J., Hurlin, C. and Rabaud, I. (2008). The Feldstein-Horioka Puzzle: A Panel Smooth Transition Regression Approach. Economic Modelling, 25, 284-299.

Georgopoulos, G. J. and Hejazi, W. (2005). Feldstein-Horioka meets a time trend. Economics Letters, 86, 353-357.

Giles, D. (1997). Causality between the Measured and Underground Economies in New Zealand. Applied Economics Letters, 4, 63-7.

Goldsmith, R. R. (1969). Financial Structure and Development, New Haven: Yale University.

Gurley, J. G. and Shaw, E. S. (1955). Financial Aspects of Economic Development. American Economic Review, 45, 515-538.

Harris, R. (1995). Using Cointegration Analysis in Econometric Modelling, London: Prentice Hall/Harvester Wheatsheaf. Hericourt, J. and Maurel, M. (2005). The Feldstein-Horioka Puzzle Revisited: An European-Regional Perspective. William Davidson Institute Working Paper, $\mathrm{n}^{\circ} 763$.

Johansen, S. (1988). Statistical Analysis of Cointegration Vectors. Journal of Economic Dynamics and Control, 12, 231-254.

Johansen, S. and Juselius, K. (1990). Maximum Likelihood Estimation and Inferences on Cointegration with Applications to the Demand for Money. Oxford Bulletin of Economics and Statistics, 52, 169-210.

Kim, S. H. (2001). The Saving-Investment Correlation Puzzle is Still a Puzzle. Journal of International Money and Finance, 20, 1017-1034. 
Kim, S., Kim, S. H. and Wang, Y. (2007). Saving, Investment and International Capital Mobility. Japan and the World Economy, 19, 279-291.

Kollias, C., Mylonidis, N. and Paleologou, S.-M. (2008). The Feldstein-Horioka Puzzle Across EU Members: Evidence from ARDL Bounds Approach and Panel Data. International Review of Economics and Finance, 17, 380-387.

Krol, R. (1996). International Capital Mobility: Evidence from Panel Data. Journal of International Money and Finance, $15,467-474$.

Kuznets, S. (1955). Economic growth and income inequality. American Economic Review, 45, 1-28.

Lucas, R. E. (1988). On the Mechanics of Economic Development. Journal of Monetary Economics, 22, 3-42.

Mamingi, N. (1994). Savings-Investment Correlations and Capital Mobility in Developing Countries. The World Bank Policy Research Working Paper, 1211.

Mavrotas, G. and Kelly, R. (2001). Old Wine in New Bottles: Testing Causality Between Savings and Growth. The Manchester School, 69, 97-105.

McKinnon, R. I. (1973). Money and Capital in Economic Development, Washington: The Brookings Institution.

Miller, S. (1988), “Are Saving and Investment Cointegrated?”, Economics Letters 27, 31-34.

Murphy, R. G. (1984). "Capital Mobility and the Relationship between Saving and Investment in OECD Countries", Journal of International Money and Finance 3, 327-342.

Nell, K. S. and Santos, L. D. (2008). The Feldstein-Horioka Hypothesis versus the Long-Run Solvency Constraint Model: A Critical Assessment. Economics Letters, 98, 66-70.

Obstfeld, M. (1995). International Capital Mobility in the 90s. In P. B. Kenen (Ed.), Understanding Interdependence: The Macroeconomics of the Open Economy (201-261). Princeton: Princeton University Press.

Oh, K., Kim, B., Kim, H. and Ahn, B. (1999). Savings-Investment Cointegration in Panel Data. Applied Economics Letters, 6, 477-480.

Pesaran, H., Shin, Y. and Smith, R. J. (2001). Bounds Testing Approaches to the Analysis of Level Relationships. Journal of Applied Econometrics, 16, 289-326.

Phillips, P.C.B. and Perron, P. (1988). Testing for Unit Root in Time Series Regression. Biometrika, 75, 335-346.

Rambaldi, A. N. and Doran, H. E. (1996). Testing for Granger Non-Causality in Cointegrated Systems Made Easy. Working Paper in Econometrics and Applied Statistics, 88, 1-22.

Rebelo, S. T. (1991). Long Run Policy Analysis and Long Run Economic Growth. Journal of Political Economy, 99, 500-521.

Robinson, J. (1952). The Rate of Interest and other Essays. London: Macmillan.

Romer, P. M. (1986). Increasing returns and long-run growth. Journal of Political Economy, 94, 1002-1032.

Roubini, N. (1988). Current Account and Budget Deficits in an Intertemporal Model of Consumption and Taxation Smoothing: A Solution to the 'Feldstein-Horioka Puzzle'? Unpublished Manuscript, Yale University.

Sachsida, A. and Caetano, A. (2000). The Feldstein-Horioka Puzzle Revisited. Economics Letters, 68, 85-88.

Summers, L. H. (1988). Tax Policy and International Competitiveness. In J. Frankel (ed.), International Aspects of Fiscal Policies (349-375), Chicago: University of Chicago Press.

Telatar, E., Telatar, F. and Bolatoglu, N. (2007). A regime Switching Approach to the Feldstein-Horioka Puzzle: Evidence from some European countries. Journal of Policy Modeling, 29, 523-533.

Toda, H. Y. and Yamamoto, T. (1995). Statistical Inference in Vector Autoregressions with possibly Integrated Processes. Journal of Econometrics, 66, 225-250.

World Bank (2007). 2007 World Development Indicators, World Bank, Washington, D. C. 
Table 1. Results of Unit-root tests

\begin{tabular}{|c|c|c|c|c|c|c|c|c|}
\hline \multirow{2}{*}{ Country } & \multicolumn{4}{|c|}{ ADF test } & \multicolumn{4}{|c|}{ PP test } \\
\hline & $S_{t}$ & $I_{t}$ & $\Delta S_{t}$ & $\Delta I_{t}$ & $S_{t}$ & $I_{t}$ & $\Delta S_{t}$ & $\Delta I_{t}$ \\
\hline Benin (1982-2005) & $\begin{array}{c}-1.895 \\
(-2.992)\end{array}$ & $\begin{array}{c}-1.799 \\
(-3.004)\end{array}$ & $\begin{array}{l}-6.057^{\circ} \\
(-1.955)\end{array}$ & $\begin{array}{l}-5.988^{\circ} \\
(-1.957)\end{array}$ & $\begin{array}{c}-2.389 \\
(-2.991)\end{array}$ & $\begin{array}{c}-1.204 \\
(-1.956)\end{array}$ & $\begin{array}{l}-8.339^{\circ} \\
(-1.955)\end{array}$ & $\begin{array}{l}-7.186^{\circ} \\
(-1.957)\end{array}$ \\
\hline Burkina Faso (1979-2005) & $\begin{array}{c}-0.657 \\
(-1.955)\end{array}$ & $\begin{array}{c}-1.805 \\
(-2.981)\end{array}$ & $\begin{array}{l}-3.772^{\circ} \\
(-1.955)\end{array}$ & $\begin{array}{l}-5.398^{\circ} \\
(-1.955)\end{array}$ & $\begin{array}{c}-0.776 \\
(-1.955)\end{array}$ & $\begin{array}{c}-1.805 \\
(-2.981)\end{array}$ & $\begin{array}{l}-3.801^{\circ} \\
(-1.955)\end{array}$ & $\begin{array}{l}-5.398^{\circ} \\
(-1.955)\end{array}$ \\
\hline Côte d'Ivoire (1965-2005) & $\begin{array}{c}-2.459 \\
(-2.925)\end{array}$ & $\begin{array}{l}-1.123 \\
(-1.949)\end{array}$ & $\begin{array}{l}-6.988^{\circ} \\
(-1.949)\end{array}$ & $\begin{array}{l}-5.334^{\circ} \\
(-1.949)\end{array}$ & $\begin{array}{c}-2.488 \\
(-2.935)\end{array}$ & $\begin{array}{c}-1.081 \\
(-1.949)\end{array}$ & $\begin{array}{l}-7.158^{\circ} \\
(-1.949)\end{array}$ & $\begin{array}{l}-5.375^{\circ} \\
(-1.949)\end{array}$ \\
\hline Mali (1967-2005) & $\begin{array}{c}-2.586 \\
(-2.941)\end{array}$ & $\begin{array}{l}-4.270^{\circ} \\
(-3.533)\end{array}$ & $\begin{array}{l}-7.231^{\prime} \\
(-1.950)\end{array}$ & $\begin{array}{l}-9.433^{\circ} \\
(-1.950)\end{array}$ & $\begin{array}{c}-2.531 \\
(-2.941)\end{array}$ & $\begin{array}{c}-4.270^{\circ} \\
(-3.533)\end{array}$ & $\begin{array}{l}-11.190^{\circ} \\
(-1.950)\end{array}$ & $\begin{array}{l}-11.321^{\circ} \\
(-1.950)\end{array}$ \\
\hline Niger (1980-2005) & $\begin{array}{l}-3.572^{\circ} \\
(-2.981)\end{array}$ & $\begin{array}{c}-2.425 \\
(-3.603)\end{array}$ & $\begin{array}{l}-5.384^{\circ} \\
(-1.954)\end{array}$ & $\begin{array}{c}-4.677^{\circ} \\
(-3.673)\end{array}$ & $\begin{array}{l}-3.583^{\circ} \\
(-2.981)\end{array}$ & $\begin{array}{c}-2.439 \\
(-3.603)\end{array}$ & $\begin{array}{l}-5.418^{\circ} \\
(-1.954)\end{array}$ & $\begin{array}{c}-4.369^{\circ} \\
(-3.612)\end{array}$ \\
\hline Senegal (1965-2005) & $\begin{array}{c}-2.260 \\
(-2.935)\end{array}$ & $\begin{array}{c}3.222 \\
(-1.950)\end{array}$ & $\begin{array}{l}-8.392^{\circ} \\
(-1.949)\end{array}$ & $\begin{array}{l}-2.612^{\circ} \\
(-2.948)\end{array}$ & $\begin{array}{c}-2.205 \\
(-2.935)\end{array}$ & $\begin{array}{c}2.897 \\
(-1.949)\end{array}$ & $\begin{array}{l}-8.392^{\circ} \\
(-1.949)\end{array}$ & $\begin{array}{l}-10.241^{\circ} \\
(-2.938)\end{array}$ \\
\hline Togo (1980-2005) & $\begin{array}{c}-3.373 \\
(-3.595)\end{array}$ & $\begin{array}{l}-3.634^{\circ} \\
(-2.986)\end{array}$ & $\begin{array}{c}-7.227^{\circ} \\
(-2.981)\end{array}$ & $\begin{array}{c}-6.573^{\circ} \\
(-1.955)\end{array}$ & $\begin{array}{c}-3.161 \\
(-3.595) \\
\end{array}$ & $\begin{array}{l}-3.646^{\circ} \\
(-2.986)\end{array}$ & $\begin{array}{l}-8.032^{\circ} \\
(-1.954)\end{array}$ & $\begin{array}{c}-6.573^{\circ} \\
(-1.955)\end{array}$ \\
\hline
\end{tabular}

Notes: The ADF statistics are compared with the critical values from MacKinnon (1996) that are in parenthesis. * denotes the rejection of the null hypothesis at the $5 \%$ significance level.

Table 2. Bounds Test Results

\begin{tabular}{|c|c|c|c|c|c|c|}
\hline Country & $\begin{array}{l}\text { Dependent } \\
\text { variable }\end{array}$ & $F$-statistic & $\begin{array}{l}5 \% \text { Lower Bound } \\
\text { Value }\end{array}$ & $\begin{array}{l}5 \% \text { Upper Bound } \\
\text { Value }\end{array}$ & Cointegration & $\begin{array}{c}\hat{\theta}_{1} \\
(\text { s.e. })\end{array}$ \\
\hline \multirow[t]{2}{*}{ Benin } & $I_{t}$ & $27.766^{\circ}$ & 4.94 & 5.73 & Yes & \multirow[t]{7}{*}{$\begin{array}{c}0.776^{\circ} \\
(0.094)\end{array}$} \\
\hline & $S_{t}$ & 3.268 & 3.15 & 4.11 & No & \\
\hline \multirow[t]{2}{*}{ Burkina Faso } & $I_{t}$ & 2.372 & 4.94 & 5.73 & No & \\
\hline & $S_{t}$ & 1.128 & 3.15 & 4.11 & No & \\
\hline \multirow[t]{2}{*}{ Côte d'Ivoire } & $I_{t}$ & 3.416 & 3.15 & 4.11 & No & \\
\hline & $S_{t}$ & 3.273 & 4.94 & 5.73 & No & \\
\hline Mali & $S_{t}$ & 5.100 & 4.94 & 5.73 & No & \\
\hline Niger & $I_{t}$ & $9.679^{\circ}$ & 4.68 & 5.15 & Yes & \multirow[t]{4}{*}{$\begin{array}{l}1.224^{*} \\
(0.338)\end{array}$} \\
\hline \multirow[t]{2}{*}{ Senegal } & $I_{t}$ & 4.180 & 4.68 & 5.15 & No & \\
\hline & $S_{t}$ & 2.788 & 3.15 & 4.11 & No & \\
\hline Togo & $S_{t}$ & 4.884 & 4.68 & 5.15 & No & \\
\hline
\end{tabular}

Table 3. Results of Toda and Yamamoto Granger non-causality tests

\begin{tabular}{|c|c|c|c|c|c|c|}
\hline \multirow{2}{*}{ Country } & \multirow{2}{*}{ Lag length $(k)$} & \multicolumn{2}{|c|}{$S_{t}$ causes $I_{t}$} & \multicolumn{2}{|c|}{$I_{t}$ causes $S_{t}$} & \multirow[t]{2}{*}{$\begin{array}{l}\text { Direction of } \\
\text { causality }\end{array}$} \\
\hline & & Wald Stat & $p$-value & Wald Stat & $p$-value & \\
\hline Benin & 3 & $8.394^{\circ}$ & 0.038 & 5.823 & 0.120 & $S \rightarrow I$ \\
\hline Burkina Faso & 1 & 0.488 & 0.484 & 2.104 & 0.146 & No \\
\hline Côte d'Ivoire & 1 & $3.666^{\circ *}$ & 0.055 & 0.152 & 0.695 & $S \rightarrow I$ \\
\hline Mali & 1 & 0.067 & 0.795 & 0.001 & 0.997 & No \\
\hline Niger & 1 & $5.247^{\circ}$ & 0.022 & 0.159 & 0.689 & $S \rightarrow I$ \\
\hline Senegal & 1 & 0.000 & 0.993 & 0.625 & 0.429 & No \\
\hline Togo & 1 & 1.113 & 0.291 & 0.295 & 0.586 & No \\
\hline
\end{tabular}

